\title{
A retrospective study on ectopic pregnancy: a two year study
}

\section{S. Sudha*, Delphine Rose Thangaraj}

Department of Obstetrics and Gynecology, Thanjavur Medical College, Thanjavur, Tamilnadu, India

Received: 28 September 2016

Revised: 07 October 2016

Accepted: 24 October 2016

\section{*Correspondence:}

Dr. V. S. Sudha,

E-mail: suvs0002@yahoo.in

Copyright: (c) the author(s), publisher and licensee Medip Academy. This is an open-access article distributed under the terms of the Creative Commons Attribution Non-Commercial License, which permits unrestricted non-commercial use, distribution, and reproduction in any medium, provided the original work is properly cited.

\begin{abstract}
Background: Diagnosis of ectopic pregnancy was frequently missed and rising trend in incidence of ectopic pregnancies necessitates awareness about risk factors, resultant morbidity and mortality. Aim of the study was to determine the incidence, clinical presentation, risk factors, treatment and morbidity and mortality associated with ectopic pregnancy.

Methods: Retrospective analysis of ectopic pregnancy was done in Government Raja Mirasudhar Hospital from January 2014 to December 2015. The following parameters: age, parity, gestational age, risk factors, clinical presentation, site of ectopic, diagnostic methods, mode of treatment and morbidity were noted.

Results: Out of 27881 deliveries, 228 were ectopic pregnancies $(0.81 \%)$.

Women with age 20-25yrs had highest incidence (42.98\%) and with least below 20yrs (9.64\%). Ectopic pregnancies were common in multiparous women than primigravida (18.42\%). Common symptoms: abdominal pain $(82.4 \%)$, amennorhea $(78.5 \%)$, bleeding per vaginum $(63.3 \%)$, asymptomatic $(12 \%)$ patients. Urine pregnancy test positive in 90.4\%. Etiology was pelvic infection $(15.78 \%)$, infertility $(7.01 \%)$, previous ectopic $(8.33 \%)$, contraception $(6.14)$, surgeries including LSCS and tubal surgeries (6.57\%). Right sided ectopic was more common. Site of ectopic: Common in fallopian tube- ampullary region $(63.15 \%)$, cornua $(13.15 \%)$, isthmus (11.40\%), fimbria $(7.01 \%)$, followed by ovarian ectopic $(3.94 \%)$ then cervical, caesarean scar, rudimentary horn pregnancy with $0.43 \%$ each. About $66.66 \%$ of ectopic was ruptured, 3/4th of these patients presented with shock at the time of presentation. Tubal abortions were seen in $20.17 \%$ of patients. Most of cases being ruptured ectopic pregnancies, salpingectomy in $90.52 \%$ and salpingoopherectomy in 3.5\%. Morbidity was blood transfusion (76.31\%), wound complications 4.38 and no mortality.

Conclusions: Early diagnosis, identifying of underlying risk factors and timely intervention in the form of conservative or surgical treatment will help in reducing the morbidity and mortality associated with ectopic pregnancy.
\end{abstract}

Keywords: Amenorrhea, Ectopic pregnancy, Risk factors, Salpingectomy

\section{INTRODUCTION}

An ectopic pregnancy occurs when a fertilized ovum implants outside the normal uterine cavity. ${ }^{1}$ It is the most important cause of maternal mortality and morbidity in the first trimester. ${ }^{2}$
Risk factors like previous ectopic pregnancy, tubal corrective surgery, tubal sterilization, intrauterine devices, documented tubal pathology, infertility, assisted reproductive techniques, PID, smoking, prior abortions, multiple sexual partners and prior delivery have been implicated in the development of the ectopic pregnancy. ${ }^{3}$ 
A knowledge of the associated risk factors helps identify women at higher risk in order to facilitate early and more accurate diagnosis. ${ }^{4}$ Most risk factors are associated with risks of prior damage to the Fallopian tube. These factors include any previous pelvic or abdominal surgery, and pelvic infection ${ }^{4}$. Chlamydia trachomatis has been linked to $30-50 \%$ of all ectopic pregnancies. ${ }^{5}$

Early diagnosis reduces the risk of tubal rupture and allows more conservative medical treatments to be employed. ${ }^{6}$

This retrospective analysis was done to determine the incidence, clinical features, risk factors, treatment and morbidity and mortality associated with ectopic pregnancy in a tertiary care hospital.

In order to decrease maternal mortality and morbidity due to ectopic pregnancy, there is a need for early diagnosis. The availability of sensitive BhCG and high-resolution sonography has resulted in earlier diagnosis and has reduced mortality rate. ${ }^{7}$

\section{METHODS}

This study was conducted in the department of obstetrics and gynaecology, Government Raja Mirasudarteaching hospital, attached to Government Thanjavur Medical college TamilNadu, India during the period of Jan 2014 to Dec 2015 for the period of 2 years.

The case sheets of the patients with ectopic pregnancy were traced through the labour ward registers and operation theatre registers. Information regarding the total number of ectopic pregnancies in the study period, details of demographic characteristics, clinical symptoms and signs, diagnostic tools used, treatment, risk factors for the ectopic pregnancy as well as associated morbidity and mortality were obtained.

\section{RESULTS}

During the study period of two years, there were 27,881 deliveries in our hospital and 228 cases were diagnosed as ectopic pregnancy giving the incidence of $0.81 \%$.

A majority of the patients $(67.54 \%)$ belonged to the age group of 20-30 yrs (Table 1).

Table 1: Age of study population.

\begin{tabular}{|lll|}
\hline Age & Number & Percentage \\
\hline$<20$ & 22 & 9.64 \\
\hline $20-25$ & 98 & 42.98 \\
\hline 26.30 & 56 & 24.56 \\
\hline$>30$ & 52 & 22.8 \\
\hline
\end{tabular}

In the present study, $81.58 \%$ were multigravida and $18.42 \%$ were primi gravida (Table 2 ).
Table 2: Gravidity.

\begin{tabular}{|lll|}
\hline & N & $\%$ \\
\hline Primi & 42 & 18.42 \\
\hline $2^{\text {rd }}$ & 74 & 32.45 \\
\hline $3^{\text {rd }}$ & 98 & 42.98 \\
\hline$>3$ & 14 & 6.14 \\
\hline
\end{tabular}

\section{Clinical presentation}

In the present study, $82.4 \%$ had abdominal pain, followed by $\mathrm{H} / \mathrm{o}$ amenorrhea in $78.5 \% \mathrm{H} / \mathrm{O}$ Bleeding pervaginum in $63.3 \%$, signs of adnexaltenderness in $46.2 \%$ and asymptomatic in $12 \%$.

UPT was positive in $90.4 \%$ of cases USG revealed rupturedectopic pregnancy in $66.66 \%$ of cases, unruptured in $14.03 \%$ of cases, heterogeneous mass with minimal free fluid $n$ POD in $20.17 \%$ of cases.

Risk factors $56.14 \%$ had no risk factors $15.78 \%$ had $\mathrm{H} / \mathrm{O}$ pelvic infection $7.01 \%$ had $\mathrm{H} / \mathrm{O}$ infertility $8.33 \%$ had prevectopic, H/O IUCD in $6.14 \% \quad \mathrm{H} / \mathrm{O}$ previoustubectomy in $6.57 \%$ (Table 3).

Table 3: Risk factors.

\begin{tabular}{|lll|}
\hline Risk factors & $\%$ & No \\
\hline H/O PID & 15.78 & 36 \\
\hline H/O & 7.01 & 16 \\
\hline H/O prev ectopic & 8.33 & 19 \\
\hline H/O IUCD & 6.14 & 14 \\
\hline H/O prevtubectomy & 6.57 & 15 \\
\hline
\end{tabular}

In $94.71 \%$ of cases ectopic pregnancy was tubal and it was more common in right side (64\%). A majority of the cases were ampullary pregnancies (63.15\%) cornual pregnancy was seen in $13.15 \%$ and $11.4 \%$ were isthmal pregnancies while $16 \%$ were in fimbria (Table 4).

Table 4: Site of ectopic.

\begin{tabular}{|lll|}
\hline Site of ectopic & Percentage & No. \\
\hline Ampulla & $63.15 \%$ & 144 \\
\hline Cornual & $13.15 \%$ & 30 \\
\hline Isthmus & $11.40 \%$ & 26 \\
\hline Fimbria & $7.01 \%$ & 16 \\
\hline Ovarian & $3.94 \%$ & 9 \\
\hline Cervical & 0.43 & 1 \\
\hline C/S Scar & $0 . .43$ & 1 \\
\hline Rudimentary & 0.43 & 1 \\
\hline
\end{tabular}

Ruptured ectopic was present in $66.66 \%$ cases on laparotomy, tubal abortion in $20.17 \%$ cases, un ruptured ectopic in 18 cases.

The most common procedure which was done was unilateral salpingectomy $90.35 \%$ of cases followed by 
salpingooophorectomy in $3.5 \%$ of cases. $6.14 \%$ of cases were medically managed with intramuscular methotrexate.

Morbidity included anaemia (73.68\%) Blood transfusion $(76.31 \%)$ and wound infection $4.38 \%$. No maternal mortality noted.

\section{DISCUSSION}

The incidence of ectopic pregnancy has increased since the last 20 years. The incidence in this present study was 8.1 for 1000 deliveries.

Majority of woman (67.54\%) in our study group belonged to the age group of 20-30 years, which is close to the studies done by Samiya Multi, et al $(75.4 \%)$ Panchal D, et al (71.66\%) and Rashmi. ${ }^{8,9}$ A Gaddagi, et al $(70.2 \%)$ most of the women in India marry at an early age and completes their family at an early age. ${ }^{10}$ This age corresponds to the age of peak sexual activity and reproduction.

In the present study group, majority of women with ectopic pregnancy were multi gravidac $(81.58 \%)$ This correlates with the studies done by Shraddha Shetty K, et al $(83.9 \%)$ Panchal D, et al $(81.66 \%)$ and Poonam, et al, (83.6). ${ }^{9,11,12}$ The higher incidence in multigravidate is probably due to previous miscarriages and infection resulting in tubal damage.

In the present study group HISTORY OF PID was present in $15.78 \%$ of the cases with ectopic pregnancy. This is correlating with the study done by Bhavna, et al $22.7 \%$ of the cases with ectopic pregnancy. ${ }^{13}$

Endosalpingitis damages the mucosa and may entrap the migrating embryo, leading to ectopic implantation; Exosalpingitis give rise to peritubal adhesion, impairing peristaltic movements, giving rise to inadequate transportation.

In our study group, $7.01 \%$ of the women with ectopic pregnancy were infertile which is correlating with the studies done by Panchal D, et al $(11.66 \%)$ and samiya Mufti, et al $(8.77 \%))^{8,9}$ The association between infertility, previous pelvic infection and tubal pathology is the possible explanation.

In our study group $8.33 \%$ of the women had history of previous ectopic pregnancy which is correlating with the studies done by Dr. Samiya Mulfti, et al (5.26\%) and Uzma Shabab, et al $(5 \%){ }^{8,14}$ There is increased risk of ectopic with previous ectopic pregnancy because it reflects the underlying tubal pathology which is almost always bilateral.

In our study group, $6.57 \%$ of the women with ectopic pregnancy had tubal sterilization which correlates with the studies done by Uzmashabab, et al (5\%) and Shrestha, et al $(5 \%) .{ }^{14,15}$ Improper surgical technique and formation of peritubal fistulas may result in ectopic pregnancy.In postpartum period, edematous, congested and friable tube increases the chance of incomplete tubal occlusion resulting in ectopic implantation.

$6.14 \%$ woman with IUCD had ectopic pregnancy which correlates with the studies done by Shraddha Shetty K, et al $(6.4 \%)$ Shrestha et al $(5 \%)$ and WM Fageeh $(5.8 \%)$ IUCD has no effect on ovulation, it prevents intrauterine pregnancy but not tubal and ovarian pregnancy. ${ }^{11,15,16}$ The risk of tubal pregnancy is more if a woman conceives with IUCD in situ.

Urine pregnancy test was positive in $90.4 \%$ of the cases which correlated with the study done by Rashmi A Gaddagi, et al (97.3\%) and WM Fgeeh (96\%). ${ }^{10,16}$

The commonest presenting complaints were abdominal pain, amenorrhea and abnormal vaginal bleeding. Clinical signs included abdominal tenderness, cervical excitation and adnexal tenderness. In Porwal Sanjay et al study, $87.5 \%$ reported with pain abdomen, bleeding per vagnina encountered in $67.5 \%$ and $90 \%$ of case had history of amenorrhea ranging from 6 weeks to 4 months. These features help in early diagnosis of ectopic pregnancies.

The urinary pregnancy test, serum $\beta$-hGG and ultrasound were the diagnostics tools used for diagnosis of ectopic pregnancy. Studies have shown that Ultrasonography should be the initial investigation for symptomatic women in their first trimester; when the results are indeterminate, the serum $\beta$ human chorionic gonadotropin concentration should be measured. Serial measurement of $\beta$-hGG and progesterone concentrations may be useful when the diagnosis remains unclear. ${ }^{17}$

The commonest site of location of the ectopic pregnancy was in the ampulla of the fallopian tube. Ampullary part of the tube was commonly involved in most of the ectopic pregnancies in other studies. ${ }^{18}$

Right, sided tubal pregnancy was present in $64 \%$ cases and left tubal involvement in $36 \%$ cases, consistent with other studies. ${ }^{19}$ Ruptured ectopic pregnancy was present in $66.66 \%, 14.03 \%$ had unruptured ectopic and tubal abortion $20.17 \%$.

As medical management needs extremely close follow up and hospitalization, surgical management is still the method of choice in our country. ${ }^{20}$ Laparaoscopy and medical therapy have now emerged as the widely used therapeutic modalities with great succession in terms of reduced morbidity, shorter hospital stay and conservation of fertility. ${ }^{21}$ However choice depends upon early identification of ectopic pregnancy and stable condition of patients. $^{22}$

Morbidity included anemia, blood transfusion and wound infection. By reducing and identifying the risk factors and 
catching the patients at the earliest it is possible to improve the prognosis so far as morbidity, mortality, and fertility are concerned. ${ }^{23}$ No maternal mortality found in our study, consistent with A, Abbas and H. Akram study. $^{24}$

\section{CONCLUSION}

The incidence if ectopic pregnancies are on the rise, as was evident by the findings of this study. All the cases were diagnosed with a high index of clinical suspicion and the USG findings added to the diagnosis. Though the recent trend in the management of ectopic pregnancy is the use of a conservative surgical or medical line of management, salpingectomy was the treatment modality which was used in the present study. This was mainly because a majority $(80 \%)$ of the cases were referred or they came late to the hospital after the ectopic pregnancy has ruptured. But fortunately there has not been even a single mortality.

\section{ACKNOWLEDGEMENTS}

I gratefully acknowledge and express my sincere thanks to our Dean. Thanjavur Medical College and Hospital, Thanjavur, India for allowing me to do this study and utilize the Institutional facilities. I would also like to thank all the medical and para- medical staffs who have helped me complete this study.

\section{Funding: No funding sources}

Conflict of interest: None declared

Ethical approval: The study was approved by the Institutional Ethics Committee

\section{REFERENCES}

1. Walker II, Ectopic pregnancy. Clinobstet Gynecol. 2007;50:89-99.

2. Mahhoob U, Masher SH. Management of ectopic pregnancy, a two-year study. I Ayub Meb Coll Abbotthad. 2006;18(4):34-7.

3. Cumminghum FG, Leveno, Bloon St, Hauth JC, Rouse DJ, Spong CY. Ectopic pregnancy; In Williams obstetrics, 23rd United States of America MC Graw Hills Publishing. 2010:238-54.

4. Karaer A, Avsar FA, Batioglu S. Risk Factors for ectopic pregnancy a case- control study. Aust NZ Obstet Gynaecol. 2006:46:521-7.

5. Turner C, Horner P. British Fertility Society Guidelines for practice. Hum Fertil (Camb). 2010;13:115-25.

6. Barnhart KT, Clinical practice, Ectopic pregancny, N Engl J Med. 2009;361379-387.

7. Ory SJ, Villaneva AL, Sand PK. Conservative treatment of ectopic pregnancy with methotrexate. AM J, obstet, Gynecol. 1986;154:1299-306.

8. Shagufta SM, Samina M, REyaz AR, Wasiqa K. Ectopic pregnancy; an anlysis of 114 cases. JKpractitioner. 2012;17(4):20-3.
9. Panchal D, Vasihanav G, Solanki K. Study of Management inpatient with Ectopic pregnancy. National journal of Integrated Research in Medicine. 2011;2(3):91-4

10. Gaddagi RA, Chandrashekbar AP. A Clinical Study of Ectopic pregnancy, Journal of clinical and Diagnostis Research. 2012;6:867-9.

11. Shetty S, Shetty A. A clinical study of Ecoptic pregnancies in a Tertiary care hospital of Mangalore,India. Innovative Journal of Medical and Health Science. 2014;4(1):305-9.

12. Poonam Y, Uprety D, Banerjee B. Ectopic Pregnancytwo years review from BPKHIS, Nepal. Kathmandu Uni. Med J., 2005;3:365-9.

13. Gupta BK, Pathania BK, Jindal M, Vohra R, Ahmed M. Risk Factors For Ectopic Pregnancy; A case Control study in Tertiary care Centre, Journal of Dental and Medical Sciences. 2014;13(3):23-7.

14. Shabab U, Hasmi HA. Different pattern of presentation of ectopic pregnancy and its management journal of surgery Pakistan (International). 2013;18:1.

15. Shrestha J, Saha R. Comparison of lapoarscopy and laparotomy in the surgical management of ecotopic pregnancy: J coll physicians Surgpak. 2012;22:760-4.

16. Fageeh WM. Diagnosis and Management of Ecotopicpregancyin king Abdul Aziz University Hosptial, a Four year Experience, Medical science. 2008:15(2).

17. Murray H, Baakdah H, Bardell T, Tuland T. Diangnosis and treatment of ectopic prergnancy. CMAJ. 2005;173(8):905-12.

18. Swenda TZ, Jogo AA. Ruptured tubal pregnancy in Makurid, North Central Nigaria. Niger J Med. 2008;17(1):75-7.

19. Udigwe GO, Umeonoihu OS, Mbachu II. Ectopic pregnancy: A 5 year review of cases at Nnamdikazikiwe University Teaching Hospital (NAUPTH) ZNEWI, NMJ. 2010:51:160-3.

20. Chatterjee S, Dey S, Chowdhury RG, Ganguli D. Ectopic pregnancy in previously infertile women pregnancy in previously outcome after laparaoscoptic Management Al amen J Med Sck. 2009;2(1):67-72.

21. Jurkovie D, Ectopic pregnancy, IN: Edmonds DK, Editor, Dew Hurst textbook of obstetrics and Gynecology $7^{\text {ed }}$, USA: Blackwell Publishers. 2007.

22. Shah N, Khan NH. Ectopic preganancy, presentation and risk factors, J collphyscianssurgpak. 2005:15:535-8.

23. Majhi AK, Roy N, Karmakar KS, Banerjee PK. Ectopic pregnancy - An analysis of 180 cases J, Indian Med Assoc: 2007:105(6):310-2.

24. Abbas A, Akram H, Ecotopic Pregnancy: Audit at Maula Bakhsh Teaching Hospital Sargodha, Prof, Med J. 2011;18(1):24-7.

Cite this article as: Sudha VS, Delphine RT. A retrospective study on ectopic pregnancy: a two year study. Int J Reprod Contracept Obstet Gynecol 2016;5:4365-8. 